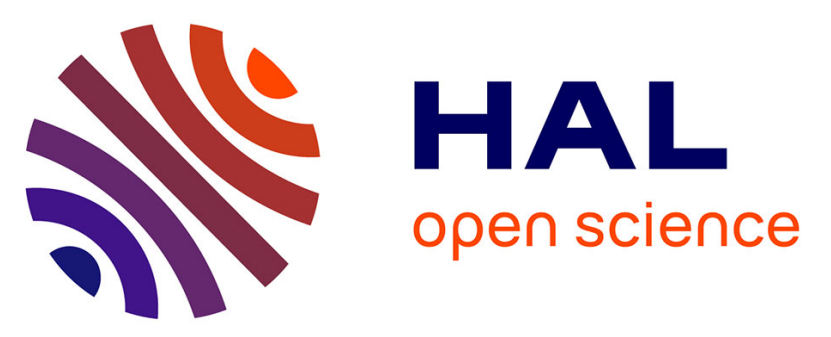

\title{
Persistence of chlorpyrifos, diazinon and dimethoate sprayed in the greenhouse environment during hydroponic cultivation of Gerbera
}

\author{
Stefanos P. Hatzilazarou, Emmanouel Charizopoulos, Euphemia
}

Papadopoulou-Mourkidou, Athanasios S. Economou

\section{To cite this version:}

Stefanos P. Hatzilazarou, Emmanouel Charizopoulos, Euphemia Papadopoulou-Mourkidou, Athanasios S. Economou. Persistence of chlorpyrifos, diazinon and dimethoate sprayed in the greenhouse environment during hydroponic cultivation of Gerbera. Agronomy for Sustainable Development, 2005, 25 (2), pp.193-199. hal-00886296

\section{HAL Id: hal-00886296 https://hal.science/hal-00886296}

Submitted on 1 Jan 2005

HAL is a multi-disciplinary open access archive for the deposit and dissemination of scientific research documents, whether they are published or not. The documents may come from teaching and research institutions in France or abroad, or from public or private research centers.
L'archive ouverte pluridisciplinaire HAL, est destinée au dépôt et à la diffusion de documents scientifiques de niveau recherche, publiés ou non, émanant des établissements d'enseignement et de recherche français ou étrangers, des laboratoires publics ou privés. 


\title{
Persistence of chlorpyrifos, diazinon and dimethoate sprayed in the greenhouse environment during hydroponic cultivation of Gerbera
}

\author{
Stefanos P. HATZILAZAROU ${ }^{a *}$, Emmanouel CHARIZOPOULOS ${ }^{\mathrm{b}}$, Euphemia PAPADOPOULOU-MOURKIDOU ${ }^{\mathrm{b}}$, \\ Athanasios S. ECONOMOU \\ ${ }^{a}$ Aristotle University, Laboratory of Floriculture, PO Box 281, 54124 Thessaloniki, Greece \\ $\mathrm{b}$ Aristotle University, Pesticide Science Laboratory, PO Box 1678, 54124 Thessaloniki, Greece
}

(Accepted 6 January 2005)

\begin{abstract}
The fate and behavior of chlorpyrifos, diazinon and dimethoate in a greenhouse installation during hydroponic cultivation of Gerbera was investigated. Their concentrations in the greenhouse air were related to their physicochemical properties. Thus, diazinon exhibited the highest concentration in the greenhouse air 2 hours after application, while chlorpyrifos and dimethoate were measured at lower concentrations. Afterwards, a rapid decrease was recorded. The concentrations of the above pesticides in the drain water of the open hydroponic system were relatively high immediately after the application but decreased rapidly during the following 3 days. In the closed hydroponic system, all the pesticides were accumulated in the nutrient solution during the first 24 hours after application but their concentration slowly decreased over the following 3 days. The highest concentrations of chlorpyrifos and diazinon were measured on the head of the spray operator. However, the highest concentration of dimethoate was measured on his chest.
\end{abstract}

airborne residues / greenhouse / organophosphate / pesticides / residue analysis / worker safety

\section{INTRODUCTION}

The production of cut flowers in greenhouses is associated with specific pest control problems that result in numerous applications of plant protection products. The Common Acceptance Directive 91/414/EEC (European Commission, 1991) deals with the authorization of plant protection products (pesticides) and the control of their use. Despite the concern that has arisen about possible health risks upon re-entry to greenhouses after the application of pesticides, little work has been reported so far concerning the persistence of pesticides in the greenhouse environment. Mestres et al. (1985) monitored the exposure to deltamethrin and dicofol in the greenhouse for 2 and 9 days, respectively, and found a rapid reduction in air concentration for both pesticides during the first $30 \mathrm{~min}$ after application. They concluded that, under normal and usual work conditions, no re-entry intervals appeared to be necessary under the given conditions of the application. Siebers and Mattusch (1996) investigated the airborne residues of five insecticides and two fungicides in the air of a greenhouse 3-4 days after application and found a rapid reduction in their air concentrations during the first 24 hours. They recommended that the personnel should avoid re-entry to the greenhouse during the 24-hour period following the application. Nilsson et al. (1996) and Nilsson and Papantoni (1996) investigated the exposure risks after spraying with vinclozolin and triadimefon in greenhouses. In their study, a rapid decline of the pesticide residues in the greenhouse air, 2 hours after application, was reported, while the pesticide residues on leaves 7 days after the application were found to be $50 \%$ of the primary initial value. They concluded that health risks of the personnel due to air exposure are negligible, but the risks of dermal exposure certainly need to be taken into consideration. Capri et al. (1999) measured potential dermal and inhalation exposure of the workers during application with procymidone in the greenhouses of the Albenga region in Italy. They reported that the potential dermal exposure during the mixing and loading phase accounted for 6-8\% of the total potential dermal exposure during the whole process, while inhalation exposure accounted for only 0.05 $0.07 \%$ of the total potential operator exposure. They concluded that the estimation coefficient set for hand-held application to ornamental crops may be inadequate for the agronomic conditions of southern Europe.

In Greece a very limited number of studies, and only in central and southern regions, have been carried out to determine occupational exposure to pesticides. Machera et al. (2001, 2003) determined the potential dermal and inhalation operator exposure from hand-held lance applications of malathion on greenhouse tomatoes at low and high spraying pressures. They found that both potential dermal operator exposure and potential inhalation exposure were increased by a factor of 7 when the application pressure was increased from 3 to 18 bars. Hatzilazarou et al. (2004) monitored the dissipation of three organochlorine and four pyrethroid pesticides in the greenhouse environment. They concluded that the spray operators

\footnotetext{
*Corresponding author: hatzilaz@agro.auth.gr
} 
were exposed to rather high concentrations of these pesticides, with endosulfan exhibiting the highest concentrations. Piperakis et al. (2003), biomonitoring with the comet assay the exposure of Greek greenhouse workers to pesticides, concluded that the agricultural workers had no detectable increase in DNA damage or alteration in the cellular response to DNA damage.

The European Commission has recognized the need for the development of a common European Predictive Operator Exposure Model. Thus, a project (EUROPOEM) has been funded to collate European Union data in a common database in support of a European model (EUROPOEM, 1996). This model should be appropriate for the different climatic conditions in both Mediterranean and Nordic areas. In southern Europe the exposure levels of the personnel are often considered higher than in countries such as the UK. New data to complete the database are required, especially from southern European conditions.

The aim of this work was to investigate, in the conditions of North Greece, the persistence of three organophosphate (chlorpyrifos, diazinon and dimethoate) pesticides in the air, nutrient solution and drain water during hydroponic cultivation of gerbera for cut flowers. Also, to assess the exposure of greenhouse personnel and the environmental contamination due to discharge of greenhouse liquid wastes.

\section{MATERIALS AND METHODS}

\subsection{Greenhouse cultivation and pesticide application}

The experiments were conducted in a glasshouse located in the experimental farm of Aristotle University (Thessaloniki, Greece). The greenhouse compartment had an area of $74 \mathrm{~m}^{2}$ with a volume of $258 \mathrm{~m}^{3}$. It was climatized automatically during the hot period by operating the fan and pad cooling system, using a set point of $26^{\circ} \mathrm{C}$. Also, shading (50\%) was provided. The relative humidity ranged from $65 \%$ to $85 \%$. The temperature, relative humidity and light irradiance in the greenhouse were monitored and recorded every $20 \mathrm{~min}$ by a computer system.

Gerbera (Gerbera jamesonii Bolus ex Hook f cvs. Molina and Lilabella) plants were grown during spring in 10-1 pots with perlite as substrate for hydroponic culture. With this technique the plants were grown on soilless substrate and the required fertilizer was applied with the irrigation. Thus, the growth conditions of the plants were easily controlled and automated systems for the regulation of the environmental conditions were applied. The pots with Gerbera plants were placed on 5 benches ( $80 \mathrm{~cm}$ from ground level) and there were 24 pots on each bench

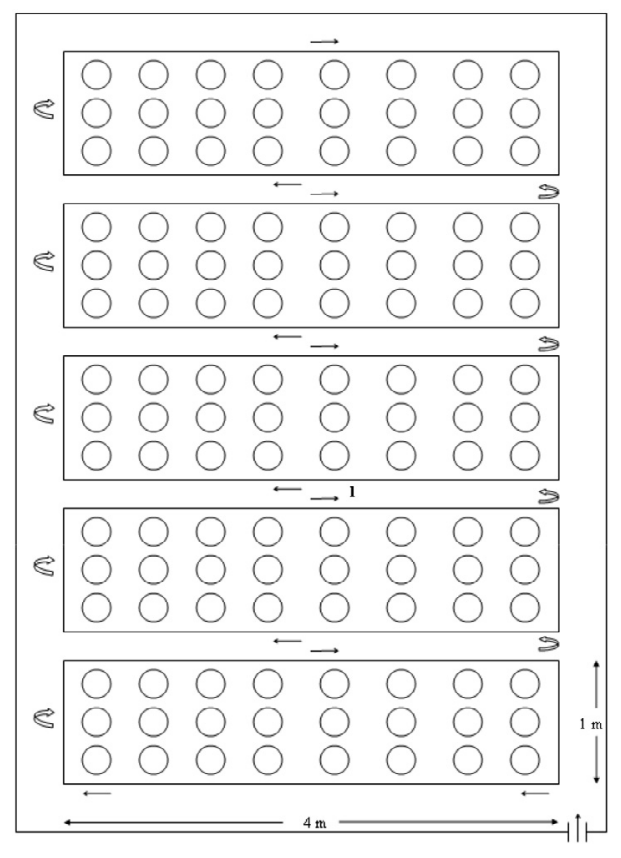

Figure 1. Scheme of the field trial and of the operator's routes during pesticide application. 1 in the scheme indicates the position of the air sampling.

(Fig. 1). Each pot had a microtube for fertirrigation. The nutrient solution was provided 6 times per day, from 8:00 am to $6: 00 \mathrm{pm}$, at 2-hour intervals with the aid of a computercontrolled unit. Each potted plant received daily $1.2 \mathrm{~L}$ of nutrient solution and about $30 \%$ of that was draining through the holes on the bottom of the pot. The benches with Gerbera plants were allocated in two fully automatic hydroponic systems. The first hydroponic system was an "open" one in which the drain water was discarded in the environment and the second hydroponic system was a "closed" one in which the drain water was recirculated. In the "closed" hydroponic system the drain water was collected in a tank and mixed with the nutrient solution for re-use. Fresh nutrient solution of the same composition, using liquid fertilizers, was provided every 15-20 days to both hydroponic systems, while the previous nutrient solution from the "closed" hydroponic system was discarded in the environment.

The commercial plant-protection products used were Dursban 48 EC (chlorpyrifos 48\%), Bazountin 60 EW (diazinon $60 \%$ ) and Rogor 40 EC (dimethoate 40.66\%). Their physicochemical and toxicological properties are shown in Table I.

Table I. Physicochemical and toxicological properties of applied pesticides (Tomlin, 1994).

\begin{tabular}{|c|c|c|c|c|c|}
\hline & $\begin{array}{c}\text { Vapor pressure }^{\mathrm{a}} \\
(\mathrm{Pa})\end{array}$ & $\begin{array}{l}\text { Water solubility } \\
\qquad\left(\mathrm{mg} \mathrm{L}^{-1}\right)\end{array}$ & $\begin{array}{l}\mathrm{LC}_{50}{ }^{\mathrm{b}} \\
\left(\mathrm{mg} \mathrm{L}^{-1}\right)\end{array}$ & $\begin{array}{c}\text { ADI } \\
\left(\mathrm{mg} \mathrm{kg}^{-1} \mathrm{~d}^{-1}\right)\end{array}$ & Substance class \\
\hline chlorpyrifos & $2.7 \times 10^{-3}$ & 1.4 & 0.2 & 0.01 & organophosphate \\
\hline diazinon & $12 \times 10^{-3}$ & 60 & 3.5 & 0.02 & organophosphate \\
\hline dimethoate & $1.1 \times 10^{-3}$ & 23800 & 0.2 & 0.01 & organophosphate \\
\hline
\end{tabular}


Table II. Application parameters of pesticides in the trial for determination of airborne residues.

\begin{tabular}{|c|c|c|c|c|c|c|c|}
\hline \multirow{2}{*}{$\begin{array}{l}\text { Date of } \\
\text { application } \\
\text { (D.M.Y.) }\end{array}$} & \multirow{2}{*}{$\begin{array}{c}\text { Mean } \\
\text { temperature } \\
\left({ }^{\circ} \mathrm{C}\right)\end{array}$} & \multirow{2}{*}{$\begin{array}{l}\text { Mean relative } \\
\text { humidity }^{\mathrm{a}} \\
(\%)\end{array}$} & \multirow{2}{*}{$\begin{array}{l}\text { Mean light } \\
\text { intensity }^{\mathrm{a}} \\
\left(\mathrm{W} \mathrm{\textrm {m } ^ { - 2 }}\right)\end{array}$} & \multicolumn{2}{|c|}{ Pesticide } & \multicolumn{2}{|c|}{ Active ingredient } \\
\hline & & & & Trade name & $\begin{array}{c}\text { Amount } \\
\left(1 \mathrm{ha}^{-1}\right)\end{array}$ & Compound & $\begin{array}{l}\text { Amount } \\
\left(\mathrm{g} \mathrm{ha}^{-1}\right)\end{array}$ \\
\hline 14.04 .01 & 23 & 88 & 64 & Dursban & 0.513 & chlorpyrifos & 246.2 \\
\hline 01.06 .01 & 27 & 68 & 118 & Bazountin & 0.216 & diazinon & 129.6 \\
\hline 16.06 .01 & 28 & 64 & 123 & Rogor & 0.540 & dimethoate & 219.6 \\
\hline
\end{tabular}

${ }^{\mathrm{a}}$ Measured $1.8 \mathrm{~m}$ above ground level.

These products were applied as tank-mix until wash-off at approximately 9:00 h using a 5-1 manual sprayer (BERTHOUD floraly 7) and the application required about $20 \mathrm{~min}$. The applications of these pesticides were carried out on 3 different dates in spring (Tab. II) according to the plant protection schedule of the specific floriculturist. In all the treatments the operator was the same person (male, 34 years old, $176 \mathrm{~cm}$ height, $70 \mathrm{~kg}$ weight). The spray operator walked in and out of the rows of the benches with the Gerbera plants, spraying all aspects of the plants. He moved the lance continuously up and down from the bottom to the top of the plants and back again. A diagram showing the route of the operator and a plan of the crop layout is shown in Figure 1. The volume of the water applied was $3.8 \mathrm{~L}$ for Dursban and 4.0 L for Bazountin and Rogor. The application rates and the greenhouse conditions during application of these pesticides are given in Table II.

\subsection{Air sampling}

In order to measure the pesticide concentrations in the greenhouse atmosphere, air was drawn into a glass tube packed with sorbent (Chromosorb, 80-120 mesh, $10 \mathrm{~g}$ ). The glass tube that contained the sorbent was mounted onto a vertical mast in the center of the greenhouse at a height of $1.2 \mathrm{~m}$. A vacuum pump calibrated to give a nominal flow rate of 3-4 $\mathrm{L} \mathrm{min}^{-1}$ was used to draw air through the sorbent; the outlet of the sorbent tube was connected to an air-flow meter to monitor the flow rate volume. In these experiments, the total volume of the collected air ranged from 200 to $1000 \mathrm{~L}$, depending upon the expected concentration in air. Air was sampled at 2, 6, 12, 24, 72 and 144 hours after application. These dates were chosen by the fact that in the air, the pesticide concentrations at the end of the 6-day period were near or below the detection limits. Extraction of the pesticides from the sorbent material took place the same or the following day. In the latter case, the sorbent material was kept in dark amber-glass bottles at $5{ }^{\circ} \mathrm{C}$ until extracted.

\subsection{Monitoring of nutrient solution and drain water}

The pesticide concentrations in the nutrient solution (recirculated) of the "closed" hydroponic system and in the drain water of the "open" hydroponic system were measured by collecting 3 samples ( $1 \mathrm{~L}$ ) in dark amber-glass bottles at 2, 24 and 72 hours after application. These dates were chosen because of the fact that the discharge of the nutrient solution and the spraying with the pesticide were not simultaneous, as happens in a commercial cultivation of Gerbera for cut flowers. Thus, according to the plant protection schedule of the specific producer, 3 days was the shortest period from the spraying to discharge of the nutrient solution. After sampling, the collected samples were kept at $5^{\circ} \mathrm{C}$ until analyzed.

\subsection{Assessment of dermal operator exposure}

Exposure of the operator to pesticides during spraying was monitored by placing two filter paper discs $(10 \mathrm{~cm}$ in diameter $)$ on the worker's chest and one on the forehead (Fig. 2). Immediately after spraying, the paper filters were placed into glass vials $(250 \mathrm{~mL})$ and taken for extraction.

\subsection{Extraction of pesticides}

The Chromosorb sorbent used for each air-sampling was extracted with ethyl acetate $(100 \mathrm{~mL})$ in a glass vial $(250 \mathrm{~mL})$ by shaking for more than 20 hours. Samples were filtered and the filtrates dried over anhydrous sodium sulfate $(1 \mathrm{~g})$ were concentrated to approximately $2 \mathrm{~mL}$ on a rotary evaporator.

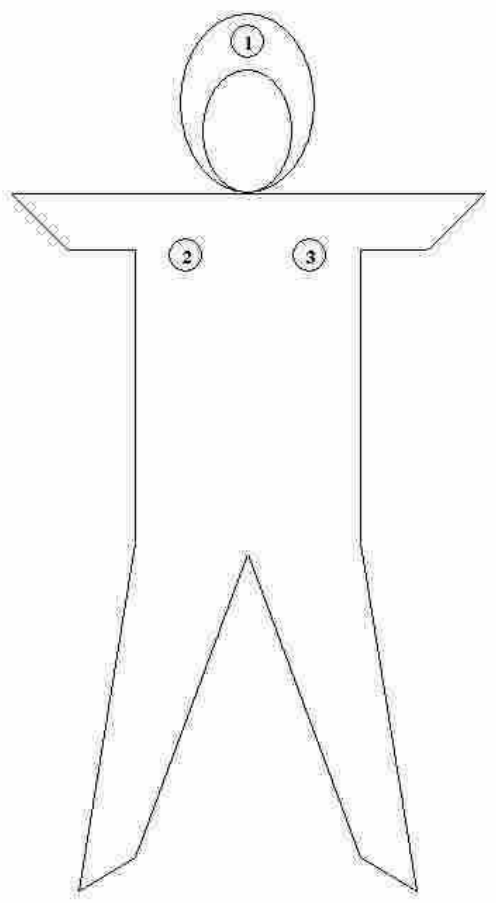

Figure 2. Position of the paper filters on the operator's body. 
These samples were transferred into glass centrifuge tubes $(5 \mathrm{~mL})$ and reduced to dryness by using a nitrogen stream. The residue dissolved in ethyl acetate $(100 \mu \mathrm{L})$ was analyzed by gas chromatography-mass spectrometry (GC-MS).

For the analysis of the pesticides in the liquid media, samples $(1000 \mathrm{~mL})$ were extracted by Solid Phase Extraction (SPE) on the Lichrolut EN cartridges. Sorbed solutes were eluted with ethyl acetate $(5 \mathrm{~mL})$ and the eluates were dried by passing through minicolumns containing granular anhydrous sodium sulfate $(1 \mathrm{~g})$. Eluates were then concentrated to small volumes, transferred into autosampler vials and concentrated to dryness under a nitrogen stream. Residues were finally dissolved into ethyl acetate (100-1000 $\mu \mathrm{L})$ depending on the expected concentration of the pesticide.

Desorption of pesticides from the filter papers was achieved using the same analytical procedure as for the Chromosorb sorbent.

\subsection{Gas chromatographic analysis}

Analysis of all the pesticides was performed on a ThermoQuest Trace GC 2000 gas chromatograph coupled to an iontrap mass spectrometric detector (GCQ). Injections $(2 \mu \mathrm{L})$ were done by an autosampler (Model AS 2000, ThermoQuest). The analytical column was a 30-m RTX-5MS (RESTEK) with i.d. $0.25 \mathrm{~mm}$ and $0.25-\mathrm{m}$ film thickness connected to a 5-m precolumn of fused silica of $0.32 \mathrm{~mm}$ i.d. Injections were done by a split/splitless injector operated in the splitless mode. The column oven temperature program was: $80^{\circ} \mathrm{C}$ (hold $1 \mathrm{~min}$ ) and up to $275^{\circ} \mathrm{C}$ at a rate of $15^{\circ} \mathrm{C} \mathrm{min}-1$. The injector and interface temperatures were set at $200{ }^{\circ} \mathrm{C}$ and $280{ }^{\circ} \mathrm{C}$, respectively. The mass spectrometric detector was operated in the Electron Impact (EI) ionization mode and full scan (50-500 amu) mode. The MS masses $(\mathrm{m} / \mathrm{z})$ that were used for quantifications were 314,179 and 125, for chlorpyrifos, diazinon and dimethoate, respectively.

\subsection{Method validation}

Fortified and blank samples were analyzed with samples from each sampling date. The recoveries of the extraction method for these pesticides ranged between 70 and $85 \%$. The efficiency of Chromosorb, as a sorbent, was tested by using two glass columns ( $10 \mathrm{~g}$ Chromosorb each) in tandem during the first two dates of sampling. In no case was significant breakthrough observed in the second column. Quantification of pesticide residues in samples was performed by using external standard calibration curves, which were linear for all compounds in the range of 1 to $100 \mathrm{ng}$, depending upon the compound.

\subsection{Statistical analysis}

Analysis of variance (one-way ANOVA) for the data concerning the nutrient solution and the drain water of the two hydroponic systems was conducted by using the SPSS program (SPSS Inc., 1993). The results are the means of at least 3 replications; separation of means was done by using the Student's t-test (Snedecor and Cochran, 1978) at $P=0.05$.

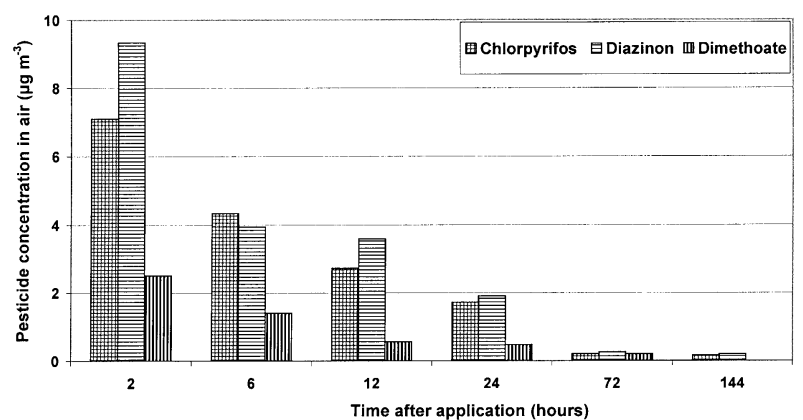

Figure 3. Concentrations $\left(\mu \mathrm{g} \mathrm{m}^{-3}\right)$ of chlorpyrifos, diazinon and dimethoate residues in the greenhouse atmosphere.

\section{RESULTS AND DISCUSSION}

\subsection{Persistence in the greenhouse air}

The concentrations of pesticides in the greenhouse air were well related to their respective vapor pressures. Diazinon, the pesticide with the highest vapor pressure among the tested compounds (Tab. I), exhibited the highest concentration in air 2 hours after application $\left(9.3 \mu \mathrm{g} \mathrm{m}^{-3}\right)$, decreasing at the end of the 6-day monitoring period to $0.19 \mu \mathrm{g} \mathrm{m}^{-3}$ (Fig. 3).

Chlorpyrifos, which was characterized by a lower vapor pressure compared with diazinon (Tab. I) but applied at almost double the rate (Tab. II), was found in the greenhouse atmosphere at lower concentrations than diazinon. The highest concentration of chlorpyrifos was measured 2 hours after application $\left(7.1 \mu \mathrm{g} \mathrm{m}^{-3}\right)$ but its concentration decreased steadily within the next 6 days (Fig. 3). Thus, 6 days after the application its concentration was measured at $0.16 \mu \mathrm{g} \mathrm{m}^{-3}$. Decline in the concentration of chlorpyrifos in the air of a rectangular greenhouse with tomato plants has been reported before (Guardino et al., 1998); in the same study, the concentration of chlorpyrifos had decreased to below the detection limit $\left(>0.3 \mu \mathrm{g} \mathrm{m}^{-3}\right) 11$ hours after insecticide application. On the contrary, in the present study, the concentration of chlorpyrifos was measured at $0.2 \mu \mathrm{g} \mathrm{m}^{-3} 3$ days after the insecticide application, while its concentration, 12 hours after the application, was $2.7 \mu \mathrm{g} \mathrm{m}^{-3}$. The different behavior of chlorpyrifos in these studies could be explained by the fact that these experiments were conducted in different types of greenhouses and under different climatic and crop conditions and under the continuous operation of vents.

Dimethoate, which has the lowest vapor pressure of the tested pesticides (Tab. I), but was applied at a much higher rate than diazinon (Tab. II), was found to have the lowest concentrations in the greenhouse atmosphere compared with the other two organophosphates and only during the first 72 hours after application (Fig. 3). Later on the concentrations were found to be below the detection limit $\left(0.1 \mu \mathrm{g} \mathrm{m}^{-3}\right)$. The highest concentration of dimethoate was $2.5 \mu \mathrm{g} \mathrm{m}^{-3}, 2$ hours after the pesticide application.

\subsection{Persistence in the nutrient solution and drain water}

The concentrations of all pesticides in the drain water of the "open" hydroponic system were relatively high immediately 


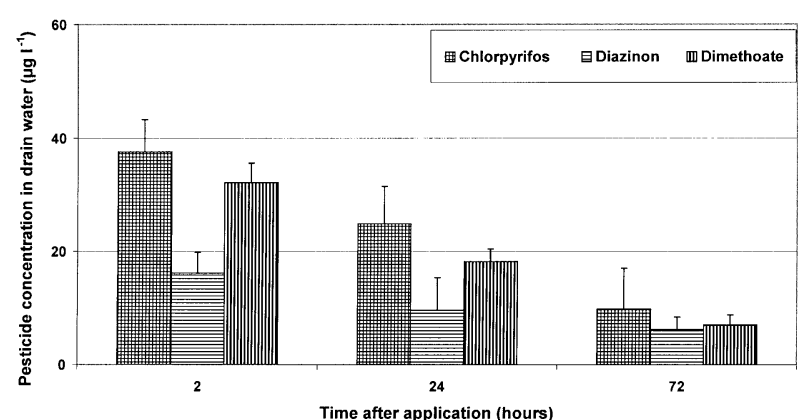

Figure 4. Concentrations $\left(\mu \mathrm{g} \mathrm{L}^{-1}\right)$ of chlorpyrifos, diazinon and dimethoate in the drain water of the "open" hydroponic system.

after application, and statistically decreased during the next 3 days (Fig. 4). The trendline concerning the decline in residue concentrations of chlorpyrifos during the 3-day monitoring period was linear $\left(\mathrm{R}^{2}\right.$ was 0.9975$)$, while the trendlines for dimethoate and diazinon were logarithmic $\left(\mathrm{R}^{2}\right.$ were 0.9923 and 0.9989 , respectively). The pesticide residues in the drain water, immediately after the spraying, were derived from the canopy wash-off, the wash-off of the soilless substrate (perlite) with fertirrigation and from the direct deposit of the spray material on the bench. In addition, during the subsequent period, the pesticide residues were derived mainly from wash-off from the soilless substrate (perlite) with fertirrigation. Since chlorpyrifos was applied at a higher application rate, its residues were present at higher concentrations compared with the other two pesticides. Thus, the highest concentration $\left(37.6 \mu \mathrm{g} \mathrm{L}^{-1}\right)$ of chlorpyrifos was measured 2 hours after application, decreasing steadily until the end of the 3-day monitoring period. On the other hand, diazinon, which was applied at the lowest application rate, was also measured at the lowest concentrations; its residue levels were measured at $16.2 \mu \mathrm{g} \mathrm{L}^{-1} 2$ hours after the application and had decreased to $6.2 \mu \mathrm{g} \mathrm{L}^{-1}$ at the end of the 3 -day period. Finally, dimethoate residues were detected at intermediate concentrations compared with the other two pesticides. Its highest concentration $\left(32.1 \mu \mathrm{g} \mathrm{L}^{-1}\right)$ was measured 2 hours after application, while at the end of the 3-day period it had declined to $7.0 \mu \mathrm{g} \mathrm{L}{ }^{-1}$.

In the "closed" hydroponic system, all organophosphorus pesticides were slowly accumulated in the nutrient solution during the first 24 hours after application (Fig. 5) and were stable or began to decrease during the next 3 days. All the trendlines concerning the change in the concentrations of pesticide residues during the 3-day monitoring period were polynomial. Chlorpyrifos was measured at the highest concentrations $\left(23.9 \mu \mathrm{g} \mathrm{L}^{-1}\right) 24$ hours after the pesticide application. Afterwards, its residues significantly declined to $19.3 \mu \mathrm{g} \mathrm{L}^{-1}$ during the 3-day monitoring period. Diazinon, although it was measured at the lowest concentrations, appeared to be the most stable pesticide since its concentrations were not significantly decreased during the 24- to 72-hour post-application period. Dimethoate was accumulated at the lowest rate in the nutrient solution during the first 24 hours after application, and decreased significantly until the end of the 3-day period.

The environmental contamination from the discharged greenhouse liquid wastes seemed to be higher in the "open"

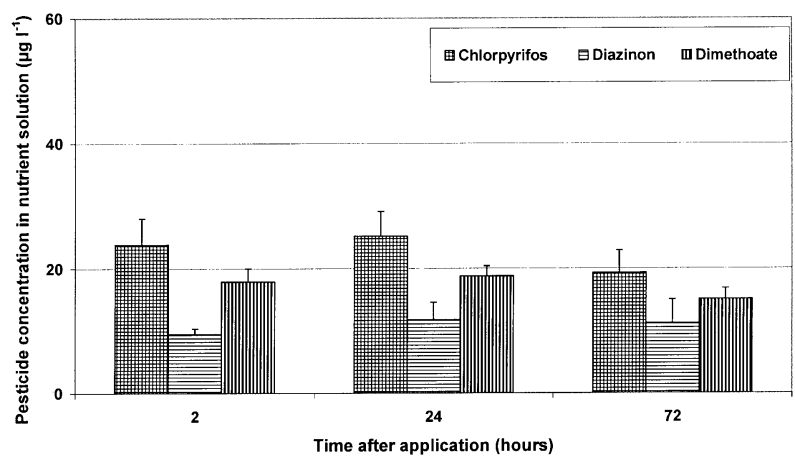

Figure 5. Concentrations $\left(\mu \mathrm{g} \mathrm{L}^{-1}\right)$ of chlorpyrifos, diazinon and dimethoate in the nutrient solution of the "closed" hydroponic system.

hydroponic system than in the "closed" one. The slow decline, with the exception of diazinon, in residue levels of the organophosphorus pesticides during the 3-day monitoring period could possibly be explained by the degradation of these pesticides in the nutrient solution (Albers et al., 1999; Kidd and James, 1991). On the other hand, diazinon hydrolyzed slowly in aqueous solution with neutral $\mathrm{pH}$ (Ku and Chang, 1998), thus indicating why diazinon was possibly more stable than the other two pesticides.

In these experiments the pesticide applications were conducted 3 days after the changing of the nutrient solution of the "closed" hydroponic system, according to the plant protection schedule of the specific producer. If by chance, the pesticide applications were made immediately after the production of the fresh nutrient solution in the "closed" hydroponic system and, given the fact that the nutrient solution of the "closed" hydroponic system is changed every 15-20 days, it seems that the contamination of the environment by pesticides present in the liquid wastes of this system would be lower than in the "open" one. This issue will be further investigated in the future.

\subsection{Potential dermal operator exposure}

Chlorpyrifos and diazinon were measured at higher concentrations on the forehead of the spray operator than on his chest (Fig. 4). However, dimethoate residues were measured at higher concentrations on the chest than on the forehead of the operator (Fig. 6). The concentration $\left(0.11 \mu \mathrm{g} \mathrm{cm}^{-2}\right)$ of chlorpyrifos on the chest of the operator was similar to that reported by Cattani et al. (2001). In this study, in spite of the different conditions of the pesticide application (spray on the ground, temperature $32-35^{\circ} \mathrm{C}$ ), the concentration of chlorpyrifos on the chest of the operator was measured at $0.08 \mu \mathrm{g} \mathrm{cm}^{-2}$.

Due to the fact that the crop area was located at a height of more than a meter from the ground and the operator sprayed up and down from the bottom to the top of the plants and back again, higher pesticide residues would be expected to be found on the head and the upper part of the body of the operator. That is why the paper filters were placed at these positions. Also, according to the European Database (EUROPOEM, 1996) and a number of studies in Mediterranean conditions (Capri et al., 1999; Machera et al., 2003), the potential inhalation exposure 


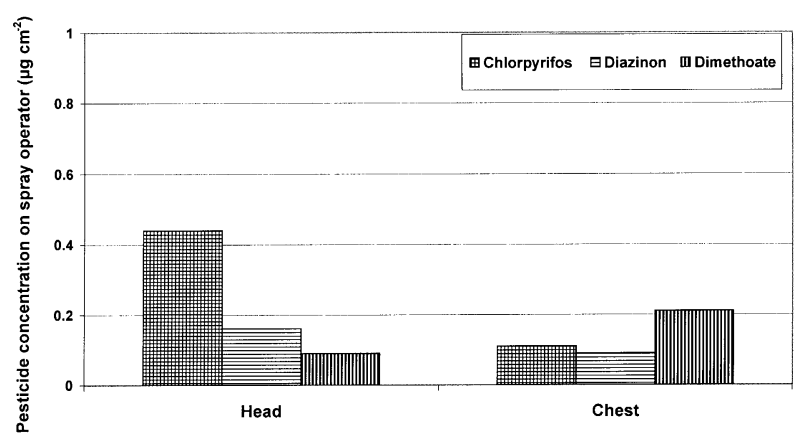

Figure 6. Exposure $\left(\mu \mathrm{g} \mathrm{cm}^{-2}\right)$ of spray operators to chlorpyrifos, diazinon and dimethoate residues.

of the operator was very limited as compared with their potential dermal exposure. For this reason, only the potential dermal exposure of the operator was measured.

In spite of the fact that the pesticide applications were made on 3 different dates, the higher concentrations on the forehead of the operator were probably due to the height (about $1.7 \mathrm{~m}$ from the ground) that the gerbera cultivation reached. In the case of dimethoate, as the operator proceeded with the spraying operation moving around the bench, he probably came in contact with the leaves of Gerbera plants by accident; this is possibly the reason for finding the highest concentrations of dimethoate on the operator's chest.

\subsection{Potential re-entry inhalation exposure}

From a number of studies (Capri et al., 1999; Hakkert, 2001) it seems that the inhalation exposure of the operator, due to limited time of exposure, was less significant than for workers reentering the greenhouse in the hours following the application. These workers spend many hours working in the greenhouse environment and the continuous exposure to pesticides may cause serious health problems in the future (Kamanyire and Karalliedde, 2004).

There are few reports relevant to the absorption of pesticides through respiration. Biological monitoring was recommended by Chester (1993) as the most precise means of estimating the absorbed dose of a pesticide. However, preliminary risk assessments of workers' re-entry exposure via a greenhouse atmosphere can be made based on the data reported here. Considering the worst scenario, in which the re-entry of the workers took place 2 hours after the application and assuming that the worker respiration rate was $10 \mathrm{~m}^{3}$ per working day (EPA, 1994); then, based on the data shown in Figure 1, the inhalation intake per working day is equivalent to $71 \mu \mathrm{g}$ for chlorpyrifos, $93 \mu \mathrm{g}$ for diazinon and $25 \mu \mathrm{g}$ for dimethoate, at two hours after the application. Assuming a 70-kg operator, this intake is equivalent to $0.001 \mathrm{mg} \mathrm{kg}^{-1}$ for chlorpyrifos, $0.0013 \mathrm{mg} \mathrm{kg}^{-1}$ for diazinon and $0.00036 \mathrm{mg} \mathrm{kg}^{-1}$ for dimethoate. These daily intakes are considerably lower than the respective Acceptable Daily Intake (ADI) values of these compounds (Tab. I).

In Greece, the workers usually re-enter the greenhouse 12 to 24 hours after the application of the pesticides. With the exception of the winter months, the temperature in the green- house is high; the windows are kept open or vents are in operation, resulting in a decline in pesticide residue levels in the greenhouse air at a faster rate than under the conditions of the present experiments.

\section{CONCLUSION}

The findings presented here confirm that when adequate protective equipment is used, the risks for the operators from exposure to pesticide residues are quite low. In the Mediterranean countries protective clothing often is not used because it is not comfortable to wear in the operating conditions of the greenhouse. Thus, more comfortable protective clothing should be created, suitable for the environmental conditions in these countries. Moreover, attention should be given to re-entry exposure of workers that enter the greenhouse after the pesticide application. In certain circumstances, chlorpyrifos and diazinon concentrations in the air can persist for at least 6 days after application. Adequate measures should be taken to assess re-entry intervals after spraying operations to minimize any health risks. Finally, the environmental contamination from the waste water of the hydroponic system should be considered, since it can be significant, especially in the "open" system. Adequate experiments should be conducted concerning the behavior of the pesticides in the nutrient solution of the "closed" hydroponic systems under different climate conditions and cultivations.

\section{REFERENCES}

Albers J., Cole P., Greenberg R., Mandel J., Monson R., Ross J., Snodgrass W., Spurgeon A., van Gemert M. (1999) Analysis of chlorpyrifos exposure and human helth: Expert panel report, J. Toxicol. Env. Heal. 2, 301-324, DOI 10.1080/109374099281151.

Capri E., Alberici R., Glass R., Minuto G., Trevisan M. (1999) Potential operator exposure to procymidone in greenhouses, J. Agr. Food Chem. 47, 4443-4449, DOI 10.1021/jf990175w.

Cattani M., Cena C., Edwards J., Pisaniello D. (2001) Potential dermal exposure to chlorpyrifos in Australian pesticide workers, Ann. Occup. Hyg. 45, 299-308, DOI 10.1016/s0003-4878(01)00027-8.

Chester G. (1993) Evaluation of agricultural worker exposure to, and absorption of, pesticides, Ann. Occup. Hyg. 37, 509-523.

EPA (1994) Methods for derivation of inhalation reference concentrations and application of inhalation dosimetry, EPA/600/8-90/ 066F, US Environmental Protection Agency, Washington DC, pp. 4-29.

European Commission (1991) Council Directive 91/414/EEC, Concerning the placing of plant protection products on the market, Off. Eur. Commun. 34, 32

EUROPOEM (1996) The development, maintenance and dissemination of a European Predictive Operator Exposure Model (EUROPOEM) Database, AIR3-CT93-1370. DGVI.FII.3, 1991-1994.

Guardino X., Obiols J., Rosell M., Farran A., Serra C. (1998) Determination of chlorpyrifos in air, leaves and soil from a greenhouse by gas-chomatography with nitrogen-phosphorus detection, high-performance liquid chromatography and capillary electrophoresis, J. Chromatogr. A 823, 91-96, DOI 10.1016/s0021-9673(98)00272-6.

Hakkert B. (2001) Refinement of risk assessment of dermally and intermittently exposed pesticide workers: A critique, Ann. Occup. Hyg 45, 23-28, DOI 10.1016/s0003-4878(00)00097-1. 
Hatzilazarou S., Charizopoulos E., Papadopoulou-Mourkidou E., Economou A. (2004) Dissipation of three organochlorine and four pyrethroid pesticides sprayed in a greenhouse environment during hydroponic cultivation of gerbera, Pest Manag. Sci. 60, 11971204, DOI 10.1002/ps. 940 .

Kamanyire R., Karalliedde L. (2004) Organophosphate toxicity and occupational exposure, Occup. Med. 54, 69-75, DOI 10.1093/occ$\mathrm{med} / \mathrm{kqh} 018$.

Kidd H., James D.R. (1991) The agrochemical handbook, 3rd ed., Royal Society of Chemistry Information Services, Cambridge, UK, pp. 2-13.

Ku Y., Chang J. (1998) Effect of solution pH on the hydrolysis and photolysis of diazinon in aqueous solution, Water Air Soil Poll. 108, 445-456, DOI 10.1023/A:1005067025615.

Machera K., Kapetanakis E., Charistou A., Goumenaki E., Glass R. (2001) Evaluation of potential dermal exposure of pesticide spray operators in greenhouses by use of visible tracers, J. Environ. Sci. Hel. 37, 113-121, DOI 10.1081/PFC-120002983.

Machera K., Goumenou M., Kapetanakis E., Kalamarakis A., Glass R. (2003) Determination of potential dermal and inhalation operator exposure to malathion in greenhouses with the whole body dosimetry method, Ann. Occup. Hyg. 47, 61-70.

Mestres R., Francois C., Vian L., Winnett G. (1985) Survey of exposure to pesticides in greenhouses, Bull. Environ. Contam. Toxicol. 35, $750-756$.
Nilsson U., Nybrant T., Papantoni M., Mathiasson L. (1996) Long-term studies of fungicide concentrations in greenhouses. 2. Fungiside concentrations in air and on leaves after different exposure times and under different climate conditions, J. Agr. Food Chem. 44 2878-2884, DOI 10.1021/jf950324k.

Nilsson U., Papantoni M. (1996) Long-term studies of fungicide concentrations in greenhouses. 3. Exposure risks after spraying in greenhouses, J. Agric. Food Chem. 44, 2885-2888, DOI 10.1021/ jf950325c.

Piperakis S., Petrakou E., Tsilimigari S., Sagnou M., Monogiudis E., Haniotakis G., Karkaseli H., Sarikaki E. (2003) Biomonitoring with the comet assay of greenhouse workers exposed to pesticides, Env. Mol. Mut. 41, 104-110, DOI 10.1002/em.10143.

Siebers J., Mattusch P. (1996) Determination of airborne residues in greenhouses after application of pesticides, Chemosphere 33 , 1597-1607, DOI 10.1016/0045-6535(96)00279-2.

Snedecor G., Cochran W. (1978) Statistical methods, 6th ed., Iowa State University Press, Iowa, USA, pp. 593-594.

SPSS Inc. (1993) Windows base system user's guide, Release 6.0, Marija Norusis/SPSS Inc, Upper Saddle River, NJ.

Tomlin C. (1994) (Ed.) The pesticide Manual, tenth ed., Crop Protections Publ., UK, p. 1341. 